DOI: https://doi.org/10.24127/ajpm.v10i2.3051

\title{
PENGARUH MODEL FLIPPED LEARNING BERBANTUAN GEOGEBRA TERHADAP KEMAMPUAN BERPIKIR KRITIS DAN MOTIVASI BELAJAR MATEMATIKA
}

\author{
Putu Mahendra Adi ${ }^{*}$, Sariyasa ${ }^{2}$, I Made Ardana ${ }^{3}$ \\ ${ }^{1 *}, 2,3$ Pendidikan Matematika,Universitas Pendidikan Ganesha, Singaraja, Indonesia \\ E-mail: $\quad$ mahendraadioffice78@ gmail.com ${ }^{*}{ }^{*}$ \\ sariyasa64@yahoo.com ${ }^{2}$ \\ ardanaimade@yahoo.com ${ }^{3)}$
}

Received 20 August 2020; Received in revised form 10 May 2021; Accepted 28 June 2021

\begin{abstract}
Abstrak
Penelitian ini bertujuan untuk mengetahui pengaruh model Flipped Learning berbantuan geogebra terhadap kemampuan berpikir kritis dan motivasi belajar matematika. Penelitian ini merupakan penelitian eksperimen semu yang menggunakan post-test only control group design. Populasi penelitian ini adalah seluruh siswa Kelas VII SMP Negeri 4 Singaraja tahun pelajaran 2019/2020 sebanyak 380 siswa dan terbagi menjadi sebelas kelas. Dalam penelitian ini, sampel yang digunakan adalah sebanyak 66 siswa yang terbagi menjadi dua kelas (kelas eksperimen dan kontrol). Sampel ditentukan dengan teknik cluster random sampling. Instrumen penelitian yang digunakan berupa angket motivasi belajar dan tes kemampuan berpikir kritis matematika. Data yang diperoleh dianalisis menggunakan uji MANOVA dengan nilai $\mathrm{F}=3861.636$ dan sig. $=0,000(\rho<0,05)$ Hasil analisis menunjukkan bahwa terdapat pengaruh positif model Flipped Learning berbantuan geogebra terhadap kemampuan berpikir kritis dan motivasi belajar matematika siswa.
\end{abstract}

Kata kunci: Kemampuan berpikir kritis; model flipped learning; motivasi belajar.

\begin{abstract}
This research aims to determine the effect of geogebra-assisted Flipped Learning models on critical thinking ability and mathematics learning motivation. This research was a quasi-experimental and using a post-test only control group design. The population of this research is all VII grade students of SMP Negeri 4 Singaraja on $2^{\text {nd }}$ semester in the academic year 2019/2020, amounting to 380 students and divided into eleven classes. The sample used was 66 students who were divided into two classes (experimental and control classes). The sample is determined by cluster random sampling technique. The research instrument used in the form of a mathematics learning motivation questionnaire and tests of the critical thinking ability in mathematics. The data obtained were analyzed using the MANOVA test with grades $F=3861,636$ and sig. $=0,000(\rho<0.05)$. The results of the analysis show that there is a positive influence of geogebra-assisted Flipped Learning models on critical thinking ability and mathematics learning motivation.
\end{abstract}

Keywords: Critical thinking ability; flipped learning; motivation.

This is an open access article under the Creative Commons Attribution 4.0 International License

\section{PENDAHULUAN}

Pendidikan di era modern adalah pendidikan yang mengedepankan industry 4.0 dengan 4C yaitu Critical Thingking, Creativity, Colaboration dan Communicaton. Siswa harus dilengkapi dengan kemampuan berpikir kritis, kreatif, berkarakter kuat yang didukung dengan kemampuan memanfaatkan teknologi informasi dan berkomunikasi. Hal ini bertujuan untuk membuka jalan keluar dari berbagai macam tantangan perkembangan yang akan datang. 
DOI: https://doi.org/10.24127/ajpm.v10i2.3051

Salah satu mata pelajaran yang dapat mengembangkan kemampuan berpikir kritis adalah matematika. Akan tetapi, kenyataannya siswa di Indonesia masih mengalami kesulitan menjawab permasalahan matematika yang berkaitan dengan kehidupan nyata. Hasil survey PISA pada tahun 2018 menentukkan bahwa prestasi belajar siswa di Indonesia pada mata pelajaran matematika berada di peringkat 72 dari 78 negara. Salah satu hal yang harus diperbaiki adalah proses berpikir siswa.

Kemampuan berpikir kritis menurut (Haryani, 2011) adalah suatu proses yang bertujuan untuk membuat keputusan rasional yang diarahkan untuk memutuskan apakah meyakini atau melakukan sesuatu. Untuk mendukung kemampuan berpikir siswa, diperlukannya sebuah motivasi sebagai jalan untuk meningkatkan prestasi belajar siswa. Menurut (Indaryati, 2015) motivasi dapat didefinisikan sebagai pe ndorong, atau motivasi adalah suatu usaha yang disadari untuk mempengaruhi tingkah laku seseorang.

Flipped Learning adalah salah satu model untuk meningkatkan motivasi dan kemampuan berpikir kritis siswa. Model Flipped Learning adalah model pembelajaran yang terbalik dimana yang seharusnya dilakukan di sekolah menjadi dirumah dan begitu juga sebaliknya. Pada saat pertemuan di kelas, siswa tinggal menyelesaikan masalah yang telah disediakan tanpa harus guru menjelaskan kembali materi yang sudah dipelajari (Irhadtanto, 2019).

Beberapa penelitian pernah dilakukan untuk melihat seberapa jauh model Flipped Learning berpengaruh terhadap kemampuan berpikir kritis dan motivasi belajar matematika siswa. Salah satunya adalah Penelitian oleh (D'Addato, 2016) yang mendapatkan hasil bahwa metodologi menggeser peran guru dan memberikan siswa kesempatan untuk merasakan tanggung jawab atas proses pembelajaran mereka sehingga lebih termotivasi dalam belajar dan bermuara pada hasil belajar yang meningkat. Sedangkan penelitian oleh (Shenny, 2017) mendapatkan hasil bahwa model Flipped Learning berpengaruh pada kemampuan berpikir kritis dan kemandirian siswa kelas VII di SMP Negeri 2 Purwokerto. Dan penelitian yang dilakukan oleh (Priatna, 2020) yang menunjukkan bahwa Keberhasilan pembelajaran flipped learning sangat bergantung pada kemandirian siswa dalam belajar dengan menggunakan bantuan aplikasi Geogebra. Dari beberapa penelitian yang sudah ada, belum ada yang meneliti tentang model Flipped Learning berbantuan geogebra terhadap berpikir kritis dan motivasi belajar matematika.

Model ini memiliki kekurangan yaitu tidak semua siswa memiliki motivasi untuk belajar secara mandiri di rumah (Adhitiya, 2015). Salah satu cara untuk mengatasinyanya adalah dengan memberikan tugas yang bersifat proyek dengan memanfaatkal teknologi, salah satunya Geogebra. Geogebra merupakan Sistem Aljabar Komputer karena mencakup fitur simbolis dan visualisasi seperti pengkodean langsung persamaan dan koordinat (Zengin, 2012). Penelitian ini memiliki tujuan untuk mengetahui dan mengkaji kembali bagaimana pengaruh model Flipped Learning berbantuan geogebra terhadap kemampuan berpikir kritis dan motivasi belajar matematika siswa.

\section{METODE PENELITIAN}

Penelitian ini merupakan eksperimen semu (quasi experimen) karena menggunakan seluruh subjek 
dalam kelompok belajar untuk diberi perlakuan, bukan menggunakan subjek yang diambil secara acak. Populasi dalam penelitian ini adalah seluruh kelas VII SMP Negeri 4 Singaraja tahun ajaran 2019/2020. Banyaknya populasi dalam penelitian ini adalah 11 kelas. Penelitian ini dilakukan dengan teknik cluster random sampling yaitu sampel dipilih secara acak sebagai kelompok (kelas). Kelas yang dimaksud merupakan kelas yang sudah terbentuk sebelumnya di sekolah tempat penelitian tanpa campur tangan serta tanpa pengacakan induvidu. Berdasarkan hasil dari teknik cluster random sampling didapatkan dua kelas yang akan menjadi kelas eksperimen dan kelas kontrol. Sampel siswa kelas VII SMP Negeri 4 Singaraja dapat dilihat pada Tabel 1.

Tabel 1. Sampel siswa kelas VII SMP Negeri 4 Singaraja

\begin{tabular}{lllc}
\hline No & Jenis Kelas & Kelas & $\begin{array}{c}\text { Banyak } \\
\text { Siswa }\end{array}$ \\
\hline 1 & Eksperimen & Kelas & 32 siswa \\
& & VII A2 & \\
2 & Kontrol & Kelas & 34 siswa \\
& & VII B1 & \\
\hline
\end{tabular}

Dalam penelitian ini terdapat 2 variabel yaitu variabel bebas dan variabel terikat. Variabel bebas dalam penelitian ini adalah Model Flipped Learning sedangkan variabel terikat dalam penelitian ini adalah kemampuan berpikir kritis dan motivasi belajar matematika. Rancangan penelitian yang digunakan dalam penelitian ini adalah post-test only control group desaign, dimana kelas kontrol dengan model pembelajaran konvensional dan kelas eksperimen dengan model pembelajaran Flipped Learning berbantuan geogebra. Selanjutnya, rancangan penelitian yang dilakukan dapat dilihat pada Tabel 2 .
Tabel 2. Rancangan penelitian

\begin{tabular}{lcc}
\hline Kelompok & Perlakuan & Evaluasi \\
\hline \multirow{2}{*}{ Eksperimen } & $\mathrm{X}_{1}$ & $\mathrm{Y}_{1}$ \\
& & $\mathrm{Y}_{2}$ \\
Kontrol & $\mathrm{X}_{2}$ & $\mathrm{Y}_{1}$ \\
& & $\mathrm{Y}_{2}$ \\
\hline
\end{tabular}

Dimodifikasi dari (Candiasa, 2018)

Keterangan:

$\mathrm{X}_{1}$ : Perlakuan dengan model Flipped Learning berbantuan geogebra

$\mathrm{X}_{2}$ : Perlakuan dengan model pembelajaran konvensional

Dengan rancangan seperti ini, memungkinkan untuk tidak melakukan pengacakan individu dalam penempatan kelompok. Keunggulan rancangan penelitian ini adalah penggunaan kelompok (kelas) yang utuh sehingga subyek penelitian tidak begitu menyadari dengan adanya eksperimen yang dilakukan. Pada penelitian ini, langkah-langkah penelitian yang ditempuh adalah sebagai berikut.

1. Menentukan sampel penelitian berupa kelas dari populasi yang telah ditentukan dan telah diuji kesetaraannya, dengan menggunakan teknik random sampling.

2. Sampel penelitian yang diperoleh akan diundi lagi untuk menentukan kelas eksperimen dan kelas kontrol.

3. Menentukan materi pelajaran dan mempersiapkan kelengkapan pembelajaran yang nantinya digunakan selama pembelajaran. Menyusun RPP dan LKS untuk kelas eksperimen dan mengkonsultasikan RPP serta LKS tersebut dengan dosen.

4. Menyusun instrumen penelitian berupa dan tes untuk mengukur kemampuan berpikir kritis matematika dan angket untuk mengukur motivasi belajar siswa. 
5. Mengadakan uji coba instrumen penelitian untuk mengetahui validitas dan reliabilitas isi.

6. Melaksanakan pembelajaran yaitu memberikan perlakuan kepada kelas eksperimen berupa model pembelajaran Flipped Learning berbantuan geogebra dan memberikan perlakuan pada kelas kontrol berupa model pembelajaran konvensional.

7. Memberikan post-test kepada kedua kelas sampel.

8. Menganalisis data hasil penelitian untuk menguji hipotesis yang diajukan.

9. Menyusun laporan penelitian

Jenis instrumen yang digunakan dalam penelitian ini berupa tes dan angket. Angket dan tes berupa angket dengan skala likert untuk mengukur tes uraian untuk mengukur kemampuan berpikir kritis dan motivasi belajar siswa. Oleh karena itu, dibuatlah seperangkat instrumen yang terdiri dari instrumen data kuantitatif. Tes yang akan digunakan pada penelitian ini adalah tes uraian yang terdiri atas 5 butir soal dengan kisi-kisi dan rubrik penskoran yang telah ditentukan. Setiap soal tes uraian kemampuan berpikir kritis mendapat skor 0 hingga 2 sehingga skor maksimal idealnya 10 . Sedangkan angket untuk motivasi terdiri dari 20 butir pernyataan yang terbagi menjadi pernyataan positif dan negative. Setiap pernyataan terdiri dari 5 pilihan jawaban dan siswa harus memilih 1 dari 5 jawaban tersebut,

Teknik analisis data penelitian ini dilakukan dengan beberapa uji yaitu:

1. Uji Coba Validitas Isi

Uji Coba validitas isi ini diuji oleh dua orang ahli yaitu dosen pendidikan matematika di Undiksha dan guru matematika di SMP Negeri
4 Singaraja. Hasilnya adalah untuk angket motivasi belajar dan tes kemampuan berpikir kritis memliliki validitas isi yang tinggi dengan nilai berturut-turut yaitu 0,72 dan 0,62 .

2. Uji Coba Validitas Konstruk

Untuk perhitungan validitas butir soal menggunakan rumus product moment. Hasilnya dari 5 butir soal tes kemampuan berpikir kritis siswa yang telah diujicobakan didapatkan 4 butir soal valid dengan no soal 2,3,4 dan 5 dan butir soal no 1 dinyatakan tidak valid, sedangkan 20 butir soal angket motivasi belajar siswa yang telah diujicobakan, ke 20 butir soal tersebut valid.

3. Uji Reliabilitas.

Pada penelitian ini, tes yang digunakan berbentuk uraian dengan menggunakan rumus Alpha Cronbach. Hasil koefisien reliabilitas tes kemampuan berpikir kritis siswa didapatkan sebesar 0,62 dengan keterangan reliabilitas tinggi, sedangkan hasil koefisien realibilitas angket motivasi belajar siswa didapatkan sebesar 0,728 dengan keterangan reliabilitas tinggi.

Setelah itu, dilanjutkan dengan uji prasyarat hipotesis. Uji prasyarat hipotesis tersebut yaitu uji normalitas, uji homogenitas, dan uji homogenitas matriks varians, uji kolinearitas dan terakhir adalah uji hipotesis. Uji hipotesis pada penelitian ini menggunakan uji MANOVA.

\section{HASIL DAN PEMBAHASAN}

Data yang diperoleh dalam penelitian ini adalah data hasil kemampuan berpikir kritis dan motivasi belajar matematika pada kelompok siswa yang mengikuti model 
DOI: https://doi.org/10.24127/ajpm.v10i2.3051

pembelajaran Flipped Learning berbantuan geogebra dan kelompok siswa yang mengikuti pembelajaran konvensional. Uji prasyarat harus terpenuhi terlebih dahulu sebelum melakukan uji Manova. Uji prasyarat tersebut adalah uji normalitas sebaran data dengan menggunakan uji Lilliefors, uji Homogenitas Varians dengan menggunakan uji Levene's, Uji Homogenitas matriks varians-kovarians dengan menggunakan SPSS 20 for windows melalui uji Box's $M$ dan terakhir adalah uji Kolinearitas variabel terikat dengan menggunakan uji korelasi product moment antar sesama variable terikat. Rangkuman untuk hasil uji Lilliefors terdapat pada Tabel 3.

Tabel 3. Rangkuman hasil uji Lilliefors

\begin{tabular}{cccc}
\hline \multicolumn{2}{c}{ Kelompok Sampel } & $\boldsymbol{L}_{\text {hitung }}$ & $\boldsymbol{L}_{\text {tabel }}$ \\
\hline $\mathrm{Y}_{1}$ & $\mathrm{X}_{1}$ & 0,1273 & 0,1566 \\
& $\mathrm{X}_{2}$ & 0,1268 & 0,1519 \\
\hline $\mathrm{Y}_{2}$ & $\mathrm{X}_{1}$ & 0,0997 & 0,1566 \\
& $\mathrm{X}_{2}$ & 0,1308 & 0,1519 \\
\hline
\end{tabular}

Keterangan:

$\mathrm{Y}_{1}=$ Kemampuan berpikir kritis Siswa

$\mathrm{Y}_{2}=$ Motivasi belajar siswa

$\mathrm{X}_{1}=$ Kelompok eksperimen

$\mathrm{X}_{2}=$ Kelompok kontrol

Berdasarkan Tabel 3 terlihat bahwa untuk semua variabel, $L_{\text {hitung }}$ $<L_{\text {tabel }}$ pada kelas yang bersangkutan. Dengan demikian $H_{0}$ diterima dan hal tersebut berarti semua sebaran data berdistribusi normal. Uji homogenitas varians digunakan untuk meyakinkan bahwa perbedaan yang diperoleh benarbenar berasal dari perbedaan antar kelompok, bukan didasarkan pada perbedaan dalam kelompok. Pengujian terhadap homogenitas varians dilakukan menggunakan uji Levene's. Pada tabel 4 disajikan rekapitulasi hasil uji homogenitas varians secara lebih jelas.
Tabel 4. Hasil uji homogenitas varians

\begin{tabular}{lll}
\hline & \multicolumn{2}{c}{ Levene's } \\
\cline { 2 - 3 } & $\mathbf{W}$ & \multicolumn{1}{c}{$\boldsymbol{F}_{\text {tabel }}$} \\
\hline $\mathrm{Y}_{1}$ & 2,44 & 3,99 \\
$\mathrm{Y}_{2}$ & 0,24 & 3,99 \\
\hline Keterangan: & \\
$\mathrm{W}=$ & Hasil perhitungan uji \\
& homogenitas varians \\
$F_{\text {tabel }}=$ & $\begin{array}{l}\text { Tabel } \mathrm{F} \text { sebagai patokan } \\
\text { pengambilan kesimpulan }\end{array}$ \\
$\mathrm{Y}_{1}=$ & $\begin{array}{l}\text { Kemampuan berpikir kritis } \\
\text { siswa }\end{array}$ \\
$\mathrm{Y}_{2}=$ & Motivasi belajar siswa
\end{tabular}

Berdasarkan Tabel 4 terlihat bahwa untuk semua variabel, $W<F_{\text {tabel }}$ pada kelas yang bersangkutan. Dengan berarti tidak ada perbedaan varians antara kelompok eksperimen dan kelompok kontrol (data homogen). Uji kolinearitas variabel terikat dilakukan dengan menggunakan uji korelasi product moment antar sesama variabel terikat. Kaidah yang digunakan untuk menyatakan kolinier tidaknya antara sesama variabel terikat adalah harga $r_{y 1 y 2}$ (harga korelasi product moment antara sesama variabel terikat). Jika $r_{y 1 y 2} \leq 0,800$ maka antar sesama variabel terikat tidak terjadi korelasi yang sangat kuat.

Adapun rangkuman hasil uji korelasi dengan product moment dapat dilihat pada Tabel 6 dan Tabel 7.

Tabel 6 Rangkuman hasil uji kolinearitas kemampuan berpikir kritis dan motivasi belajar siswa kelompok eksperimen

\begin{tabular}{lll}
\hline & $\mathbf{X}_{\mathbf{1}} \mathbf{Y}_{\mathbf{2}}$ \\
\hline$r_{y 1 y 2}$ & $\mathrm{X}_{1} \mathrm{Y}_{1}$ & 0.10 \\
\hline
\end{tabular}

Keterangan :

$\mathrm{X}_{1} \mathrm{Y}_{1}=$ Kemampuan berpikir kritis siswa kelompok eksperimen

$\mathrm{X}_{1} \mathrm{Y}_{2}=$ Motivasi belajar siswa kelompok eksperimen 
DOI: https://doi.org/10.24127/ajpm.v10i2.3051

Dari tabel 6 ditunjukkan bahwa harga korelasi product moment antara sesama variabel terikat sebesar $r_{y 1 y 2}=0,10 \leq 0.800$. Dengan demikian antara kemampuan berpikir kritis dan motivasi siswa di kelompok eksperimen tidak berkolerasi. Selanjutnya, rangkuman hasil uji kolinearitas dapat dilihat pada Tabel 7.

Tabel 7. Rangkuman hasil uji kolinearitas motivasi dan kemampuan berpikir kritis siswa kelompok kontrol

\begin{tabular}{|c|c|}
\hline & $\mathbf{X}_{2} \mathbf{Y}_{2}$ \\
\hline$r_{y 1 y 2}$ & $\mathrm{X}_{2} \mathrm{Y}_{1}$ \\
\hline
\end{tabular}

Keterangan :

$\mathrm{X}_{2} \mathrm{Y}_{1}=$ Kemampuan berpikir kritis siswa di kelompok kontrol
$\mathrm{X}_{2} \mathrm{Y}_{2}=$ Motivasi belajar siswa di kelompok kontrol

Sedangkan, dari Tabel 7 ditunjukkan bahwa harga korelasi product moment antara sesama variabel terikat sebesar $\quad r_{y 1 y 2}=0,13 \leq 0.800$. Dengan demikian antara kemampuan berpikir kritis dan motivasi siswa di kelompok kontrol tidak terdapat kolerasi. Hipotesis dari penelitian ini yaitu model Flipped Learning berbantuan geogebra berpengaruh positif terhadap kemampuan berpikir kritis dan motivasi belajar matematika. Selanjutnya, untuk hasil analisis yang dilakukan dengan MANOVA dapat dilihat pada Tabel 8 .

Tabel 8. Hasil analisis uji MANOVA

\begin{tabular}{|c|c|c|c|c|c|c|}
\hline \multicolumn{7}{|c|}{ Multivariate Tests ${ }^{a}$} \\
\hline Effect & Value & $\mathbf{F}$ & Hypothesis & df & Error df & Sig. \\
\hline \multirow{4}{*}{ Kelas } & Pillai's Trace & .992 & $3861.636^{b}$ & 2.000 & 63.000 & .000 \\
\hline & Wilks' Lambda & .008 & $3861.636^{\mathrm{b}}$ & 2.000 & 63.000 & .000 \\
\hline & Hotelling's Trace & 122.592 & $3861.636^{\mathrm{b}}$ & 2.000 & 63.000 & .000 \\
\hline & Roy's Largest Root & 122.592 & $3861.636^{\mathrm{b}}$ & 2.000 & 63.000 & .000 \\
\hline
\end{tabular}

Berdasarkan Tabel 8, diperoleh nilai-nilai statistik Pillai's Trace, Wilks'Lambda, Hotelling's Trace, dan Roy's Largest Root masing-masing F = 3861,636 dan memiliki signifikansi kurang dari $0,05(\mathrm{p}<0,05)$. Hasil ini dijadikan dasar dalam mengambil keputusan. Adapun keputusan yang dapat diambil adalah model Flipped Learning berbantuan geogebra berpengaruh positif terhadap kemampuan berpikir kritis dan motivasi belajar matematika siswa.

Terjadinya perbedaan kemampuan berpikir kritis dan motivasi belajar matematika siswa salah satunya disebabkan adanya perbedaan perlakuan pada kedua kelas, yaitu penerapan pembelajaran menggunakan model
Flipped learning berbantuan geogebra pada kelas eksperimen dan pembelajaran konvensional pada kelas kontrol. Selain itu penggunaan media geogebra memberikan memberikan kesempatan kepada siswa untuk melakukan penemuan dengan memanipulasi alat peraga tersebut. Hal tersebut menyebabkan dapat membangun pengetahuan siswa serta mendorong siswa untuk memahami konsep sehingga dapat mempersingkat waktu untuk memahami tujuan pembelajaran (Suweken, 2014). Sejalan dengan penelitian yang dilakukan oleh (Usmadi, 2019) yang mengungkap bahwa dengan model Flipped Learning ini dapat meningkatkan hasil belajar, motivasi yang tergolong tinggi dan 
minat belajar siswa juga tergolong tinggi terhadap materi pembelajaran matematika.

Model Flipped Learning berbantuan geogebra ini merupakan pembelajaran yang mengkondisikan siswa aktif dalam pembelajaran dan memaksimalkan pengajaran tidak langsung yang dapat diakses secara daring oleh siswa (Johnson, 2013). Dari hasi penelitian, ditemukan bahwa siswa dapat mengeluarkan pendapatnya secara bebas dan seluas-luasnya sehingga siswa menjadi bergairah karena materi sudah diberikan sebelum pertemuan dikelas berlangsung dan diberikan dalam bentuk video yang memudahkan untuk memahami dalam mengikuti proses pembelajaran yang menyebabkan kemampuan berpikir kritis dan motivasi belajar matematika siswa menjadi meningkat. Dalam penelitian ini, siswa ingin guru memberikan lebih banyak video pembelajaran yang dipelajari di rumah karena video tersebut membantu siswa memahami materi dengan bisa diputar berulang kali, sedangkan di sekolah, guru jarang untuk mengulangi materi sehingga ada siswa yang belum memahami materi yang disajikan.

Berdasarkan penemuan dilapangan, guru menerapkan pembelajaran ini dengan mengikuti 4 pilar yaitu Flexibel Environment, Learning Culture, Intentional Content, Professional Educator (Facione, 2011). Hal yang dapat meningkatkan motivasi melalui model pembelajaran ini yaitu pada saat siswa menganalisis dan memahami video untuk mengerti materi yang disampaikan dan mencari pertanyaan yang akan diajukan pada saat kelas berlangsung di sekolah dengan materi yang telah disiapkan oleh guru. Terlihat dilapangan bahwa siswa merasa termotivasi untuk memahami materi berikutnya yang terlihat dari siswa bersungguh-sungguh dalam belajar matematika, mencari hal-hal baru yang berhubungan dengan pelajaran matematika, berusaha mendapatkan pujian dan menghidari hukuman yang diberikan oleh guru/ Menurut (Mertasari, 2016). Hasil belajar akan optimal jika ada motivasi yang maksimal. Siswa yang memiliki motivasi belajar yang tinggi akan tergerak untuk mencari, menggali dan mengembangkan bakatnya sehingga dalam diri siswa tersebut terdorong untuk belajar dan menemukan pemahamannya sendiri (Sariyasa, 2019). Hal ini sejalan dengan penelitian (Suryacitra, 2018) dimana rata-rata nilai hasil belajar siswa yang menggunakan model Flipped Learning lebih tinggi dibandingkan dengan menggunakan model pembelajaran konvensional dalam materi vektor.

\section{KESIMPULAN DAN SARAN}

Berdasarkan hasil penelitian dan pembahasan dapat disimpulkan bahwa terdapat pengaruh positif model Flipped Learning berbantuan geogebra terhadap kemampuan berpikir kritis dan motivasi belajar matematika siswa kelas VII SMP Negeri 4 Singaraja dan secara khusus dapat disimpulkan bahwa kemampuan berpikir kritis dan motivasi belajar matematika siswa yang mengikuti pembelajaran dengan model Flipped Learning berbantuan geogebra lebih tinggi daripada siswa yang mengikuti pembelajaran konvensional.

Berdasarkan hasil kesimpulan di atas, diharapkan peneliti lain yang ingin melakukan penelitian serupa mengenai model Flipped Learning berbantuan Geogebra hendaknya memperhatikan hambatan-hambatan yang ditemui dalam pelaksanaan penelitian, sehingga dijadikan pertimbangan untuk kedepannya. 


\section{DAFTAR PUSTAKA}

Adhitiya, E. N. (2015). Studi Komparasi Model Pembelajaran Traditional Flipped Dengan Peer Instruction Flipped Terhadap Kemampuan Pemecahan Masalah. Unnes Journal of Mathematics Education, 4(2). https://doi.org/10.15294/ujme.v4i 2.7451

Candiasa, I. M. (2018). Identifikasi Faktor-Faktor yang Mempengaruhi Kemampuan Pemecahan Masalah Matematika. NUMERICAL: Jurnal Matematika Dan Pendidikan Matematika, 2(2), 153. https://doi.org/10.25217/numerica 1.v2i2.276

D'Addato, T. (2016). An Inquiry into Flipped Learning in Fourth Grade Math Instruction. The Canadian Journal of Action Research, 17(2), 33-55. https://doi.org/10.33524/cjar.v17i 2.261

Facione, A. (2011). Critical Thinking: What It Is and Why It Counts. Measured Reasons and The California Academic Press, Millbrae, $C A$.

Haryani, D. (2011). Pembelajaran Matematika Dengan Pemecahan Masalah Untuk Menumbuhkembangkan Kemampuan Berpikir Kritis Siswa. Prosiding Seminar Nasional Penelitian, Pendidikan Dan Penerapan MIPA, Fakultas MIPA, Universitas Negeri Yogyakarta, 1980, 121-126.

Indaryati. (2015). Pengembangan Media Komik Pembelajaran Matematika Meningkatkan Motivasi Dan Prestasi Belajar Siswa Kelas V Developing Comic Media for the Teaching of Mathematics To
Enchance the Motivation and Mathematics Learning Outcomes Grade V. Jurnal Prima Edukasia, $3(1)$, 84-96. https://journal.uny.ac.id/index.php /jpe/article/view/4067

Irhadtanto, B. (2019). Pengaruh model pembelajaran Flipped Classrom Tipe traditional Flipped terhadap Hasil Belajar Matematika Siswa pada materi bangun ruang sisi datar. Jurnal Math Educator Nusantara: Wahana Publikasi Karya Tulis Ilmiah Di Bidang Pendidikan Matematika, 5(2), 153-163.

Johnson, G. B. (2013). Student perceptions of the flipped classroom. University of British Columbia.

Mertasari, N. M. S. (2016). Pengaruh Model Pembelajaran ARIAS Terhadap Motivasi dan Prestasi Belajar Matematika Siswa Kelas VII SMP Negeri 5 Melaya. Jurnal Pendidikan Matematika Undiksha, 5(2).

Priatna, N. (2020). Pengembangan Bahan Ajar Model Pembelajaran Blended Learning Berbantuan Geogebra untuk Meningkatkan Kemampuan Berpikir Kritis Matematis Siswa SMA. Edsence: Jurnal Pendidikan Multimedia, 2(2), 93-100. https://doi.org/10.17509/edsence.v $2 \mathrm{i} 2.22871$

Sariyasa. (2019). Penerapan Model Pembelajaran berbasi Masalah Untuk Meningkatkan Motivasi dan Prestasi Belajar Matematika Siswa Kelas VIII B SMP N 7 Singaraja. Jurnal Pendidikan Dan Pembelajaran Matematika Indonesia, 8(2), 93-101.

Shenny, Y. (2017). Pengaruh Pembelajaran Flipped Learning 
DOI: https://doi.org/10.24127/ajpm.v10i2.3051

TTerhadap Kemampuan Berpikir Kritis dan Kemandirian Belajar Siswa Kelas VIII SMP Negeri 2 Purwokerto. Universitas Muhammadiyah Purwokerto.

Suryacitra, G. E. (2018). Efektivitas Penerapan Model Pembelajaran Flipped Learningdi Kelas X MIPA SMA Negeri 1 Karanganom Tahun Ajaran 2017/2018 pada Materi Vektor. Universitas Sanata Dharma, Yogykarta.

Suweken, G. (2014). Pengaruh model pembelajaran berbasis masalah dengan media pembelajaran berbantuan geogebra terhadap prestasi belajar matematika siswa ditinjau dari tingkat ketangguhan siswa. Jurnal Pendidikan Dan Pembelajaran Matematika Indonesia, 3(1).

Usmadi, U. (2019). Penerapan Strategi Flipped Classroom dengan Pendekatan Scientific dalam Pembelajaran Matematika pada Kelas XI SMKN 2 Padang Panjang. Jurnal Eksakta Pendidikan (Jep), 3(2), 192. https://doi.org/10.24036/jep/vol3iss $2 / 333$

Zengin, Y. (2012). The effect of dynamic mathematics software geogebra on student achievement in teaching of trigonometry. Procedia - Social and Behavioral Sciences, 31(2011), 183-187. https://doi.org/10.1016/j.sbspro.20 11.12.038 